\title{
AETIOLOGY OF ATHETOSIS WITH SPECIAL REFERENCE TO NEONATAL ASPHYXIA, IDIOPATHIC ICTERUS, AND ABO-INCOMPATIBILITY*
}

\author{
BY \\ P. PLUM \\ From the University Clinic of Paediatrics, Rigshospital, Copenhagen, Denmark
}

(RECEIVED FOR PUBLICATION AUGUST 27, 1964)

In the present paper the aetiology of congenital athetosis has been studied by examining the relative importance of the following factors: (1) neonatal asphyxia without icterus, (2) neonatal icterus of unknown origin, (3) neonatal icterus due to ABOand $\mathrm{Rh}$-sensitization, and (4) prematurity.

\section{Material and Methods}

The case material comprises all patients with congenital athetosis seen in our clinic from 1949 to 1963 inclusive, a total of 173. The age of the patients at first examination, last examination, and death, is given in Figs. 1 and 2.

It is seen that most of the deaths during childhood occur within the first three years of life: 85 patients, $49 \%$, were seen during their first year of life; of these 85 patients, $41 \%$, died. Of patients first seen after their first year of life, only $7 \%$ died. All patients have been examined by the author, in most cases repeatedly.

Neonatal History. There were 96 children born in hospital or in a private clinic, and 32 children born at home but admitted to hospital during the neonatal period. Information was obtained from the hospital records for these 128 children. The remaining 45 were born at home and not admitted to hospital during the first weeks of life; in these, information was supplied by the parents and by their physicians. All parents in addition filled in a detailed questionnaire, and later the questionnaire was discussed, usually on several occasions. The reliability of the information given by parents was checked by comparing it with that obtained from hospitals, and was found satisfactory.

Serological Examinations. These were carried out in children and their mothers in practically all cases. Most of the serological examinations were carried out at the Blood Bank of the Rigshospital (Head: Erik Freiesleben, M.D.) and some at the Blood Group Department of the State Serum Institute. The following laboratory tests were made. (a) The child: $\mathrm{ABO}$ and $\mathrm{Rh}$ groups, direct

* This study was supported by a PHS Research Grant B-2408 from The National Institute of Neurological Diseases and Blindness, Bethesda, U.S.A., and by The Danish Cerebral Palsy Fund.

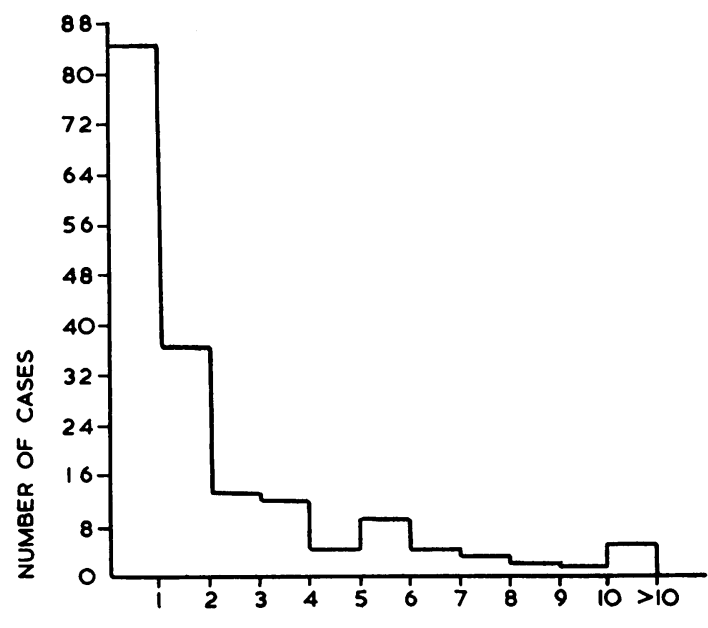

AGE IN YEARS AT FIRST EXAMINATION

Fig. 1.-Age in years at first examination of 173 cases of athetosis.

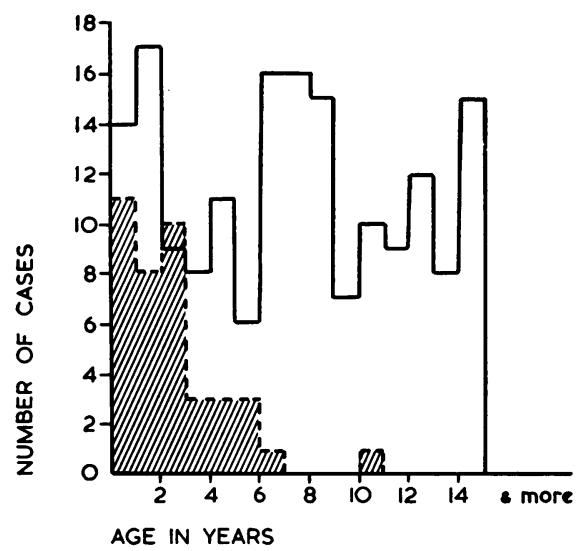

FIG. 2.-Age in years at last examination of 173 cases of athetosis (white area). Age at death of 41 cases of athetosis (hatched area). 
Coombs test, and a direct Munk-Andersen (1956) conglutination test in the newborn, if the child's red cells were found to be $\mathrm{ABO}$-incompatible with the serum of the mother. (b) Compatibility test between the child's red cells and the mother's serum: the test was performed with a saline suspension at $37^{\circ} \mathrm{C}$. and followed by an indirect Coombs test. (c) The mother: $\mathrm{ABO}$ and $\mathrm{Rh}$ groups; examination for complete and incomplete antibodies. If ABO incompatibility was found, the mother's serum was examined for specific haemolysins and immune antibodies against the child's ABO antigens.

\section{Definitions}

Athetosis: a non-progressive condition, characterized by involuntary movements, lack of co-ordination, paresis, and intermittent hypertonicity. The irregular hyperkinetic movements may appear spontaneously or only under emotional or intentional stress. Only congenital cases have been included.

Kernikterus. The following signs have been considered as clinical evidence of kernikterus in the newborn baby: opisthotonus, head bent backwards, increased muscular tone, convulsion-like attacks, attacks of crying, cyanotic attacks, flaccidity, trembling, abnormal eye movements, abnormal jerky or 'fighting' movements of upper extremities, oblique position of head, fever, abnormal respiration, poor feeding, or swallowing.

Icterus I: mild neonatal jaundice of a few days' duration; icterus II: pronounced neonatal jaundice lasting less than 3 weeks; icterus III: pronounced neonatal jaundice lasting for more than 3 weeks.

Asphyxia I: mild neonatal asphyxia, lasting in most cases only for a few minutes and in no case for more than 15 minutes; asphyxia II: pronounced neonatal asphyxia, lasting for 15-29 minutes; asphyxia III: pronounced neonatal asphyxia, lasting for $\mathbf{3 0}$ minutes or more.

Blood-group Immunization. In cases of $\mathrm{Rh}$ incompatibility, the usual criteria were followed. In cases of ABO incompatibility the criteria of the Blood Bank of the Rigshospital were accepted. Antibodies against A or B were described as being of immune character, only if the antibody titre in the indirect Coombs test was three dilutions or more higher than the saline antibody titre. If, for example, the saline titre was 256 and the indirect Coombs titre was 2,048 , the antibody was described as immune. If the saline titre was 2,048 and the indirect Coombs titre was 4,096 , the antibody was described as not being of immune character. A positive direct MunkAndersen test on the red cells of the child was considered to be supporting evidence for the presence of immune antibodies.

Hyperkinesia I: spontaneous or induced hyperkinetic movements of slight degree; hyperkinesia II: of moderate degree; hyperkinesia III: of excessive degree.

Motor handicap $I$ : does not prevent the patient from carrying out the movements necessary in daily life. Motor handicap II: renders it impossible to carry out ordinary movements in a normal manner, and when they are carried out there is considerable exertion. Motor handicap III: prevents the patient from carrying out voluntary movements in an efficient manner.

Speech handicap I: speech is easily understandable, but not normal for the age; speech handicap II: the patient can speak, but is understood with difficulty; speech handicap III: the patient has practically no spoken language, perhaps a few words.

\section{Results}

Neonatal Asphyxia as a Cause of Athetosis. During 1949 to 1963 inclusive, when the cases of athetosis were observed, changes had taken place with regard to the relative frequency of the possible aetiological factors, namely icterus of unknown origin (idiopathic icterus), icterus due to blood-group immunization, and asphyxia. The case material of athetosis has been presented with respect to these factors in Table 1. The series shows a relative and absolute decrease in frequency of cases with a history of asphyxia without icterus: this tendency may probably be explained by the increasing interest of obstetricians in preventing neonatal asphyxia.

The correlation between degree of icterus, degree of asphyxia, immunization, and prematurity is presented in Table 2, which shows that in all but 5 cases, the children had either neonatal icterus or neonatal asphyxia, or both. In 31 , there was neonatal asphyxia without icterus. It can also be seen that asphyxia in these 31 children was most often pronounced and that most of them were full-term infants. In addition, it is clear that the combination of neonatal icterus and neonatal asphyxia is less frequent in cases where the icterus is due to immunization than in cases where it is not due to immunization.

Another explanation for the relative increase in post-icteric cases (Table 1), and the corresponding decrease in post-asphyxial cases, might be that some years ago neonatal icterus was more often overlooked or forgotten. When, however, the group of cases with a history of neonatal asphyxia without neonatal icterus is compared with the group of cases with a history of neonatal icterus, with or without neonatal asphyxia, such a conclusion is seen to be statistically most unlikely.

In Tables 3 and 4, all cases of athetosis are divided into three groups ( $\mathrm{A}, \mathrm{B}$, and $\mathrm{C}$ ) according to the presence or absence of neonatal icterus and neonatal asphyxia. In Table 3 groups $A, B$, and $C$ are correlated with other factors, such as birth weight, complicated delivery, history of icterus in sibs, and 
TABLE 1

179 CASES OF CONGENITAL ATHETOSIS: YEAR OF BIRTH IN RELATION TO NEONATAL ICTERUS, ASPHYXIA, AND BLOOD SENSITIZATION

\begin{tabular}{|c|c|c|c|c|c|c|c|}
\hline Year of Birth & $\begin{array}{l}\text { No. of } \\
\text { Cases* }\end{array}$ & $\begin{array}{c}\text { Icterus } \\
(\%)\end{array}$ & $\begin{array}{c}\text { Icterus } \\
\text { and } \\
\text { Sensitization } \\
(\%)\end{array}$ & $\begin{array}{c}\text { Icterus } \\
\text { Without } \\
\text { Sensitization } \\
(\%)\end{array}$ & $\begin{array}{c}\text { Asphyxia } \\
(\%)\end{array}$ & $\begin{array}{c}\text { Asphyxia } \\
\text { Without } \\
\text { Icterus } \\
(\%)\end{array}$ & $\begin{array}{c}\text { Insufficient } \\
\text { Information } \\
(\%)\end{array}$ \\
\hline $\begin{array}{c}\text { Before } 1949 \\
1949-53 \\
1954-58 \\
1959-63\end{array}$ & $\begin{array}{l}32 \\
65 \\
62 \\
20\end{array}$ & $\begin{array}{r}53 \\
69 \\
82 \\
100\end{array}$ & $\begin{array}{l}19 \\
31 \\
45 \\
25\end{array}$ & $\begin{array}{l}34 \\
38 \\
37 \\
75\end{array}$ & $\begin{array}{l}44 \\
38 \\
32 \\
20\end{array}$ & $\begin{array}{r}22 \\
17 \\
15 \\
0\end{array}$ & $\begin{array}{r}22 \\
8 \\
2 \\
0\end{array}$ \\
\hline
\end{tabular}

* All cases of athetosis were included, but 6 infants who died with kernikterus in 1963 could not be included in the statistical analysis.

TABLE 2

DISTRIBUTION OF 173 CASES OF ATHETOSIS WITH REGARD TO DEGREE OF NEONATAL ICTERUS, DEGREE OF NEONATAL ASPHYXIA, BLOOD GROUP SENSITIZATION, AND BIRTH WEIGHT

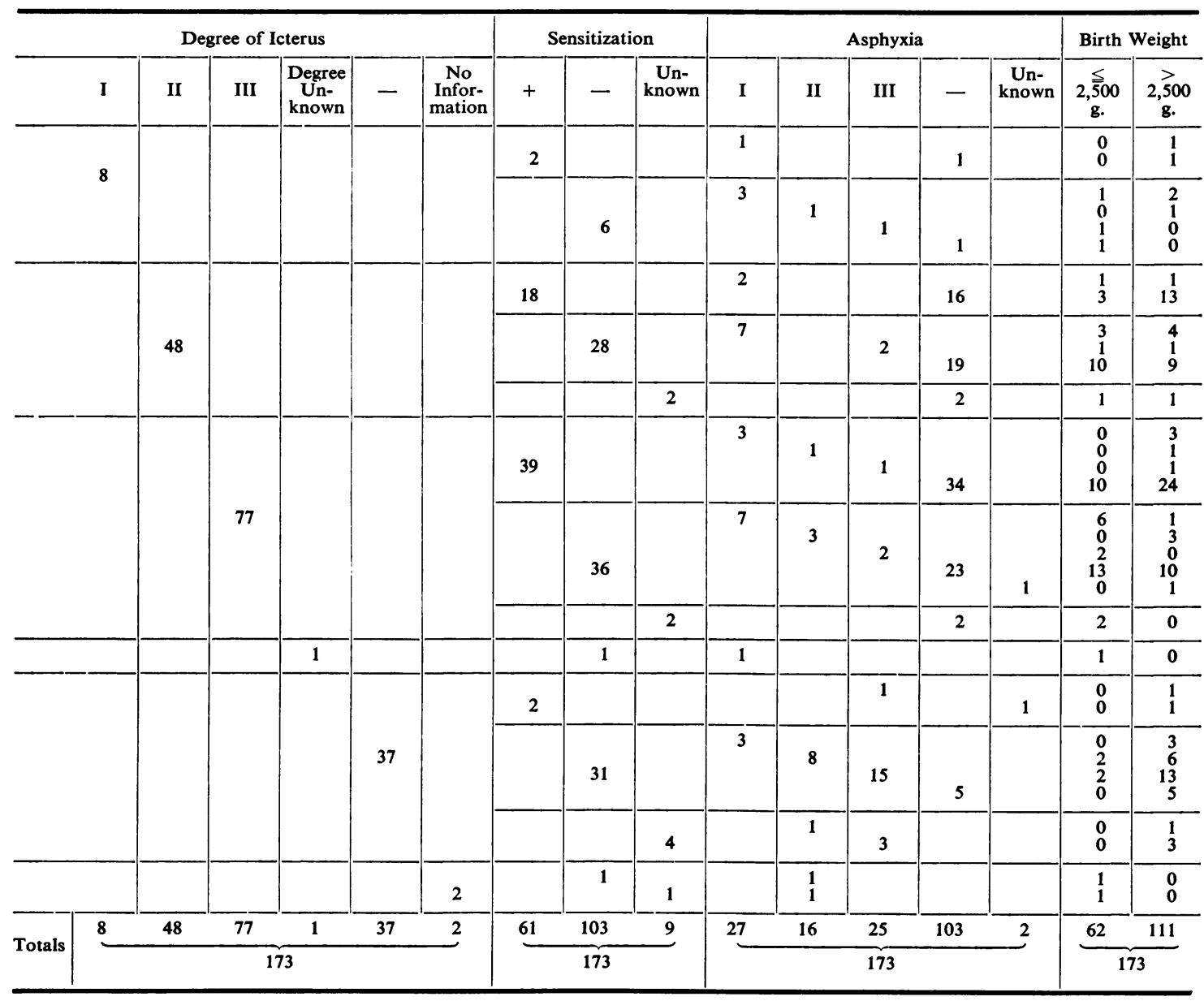


TABLE 3

RELATION BETWEEN NEONATAL HISTORY WITH REGARD TO ICTERUS AND ASPHYXIA, AND SOME OTHER FACTORS

\begin{tabular}{|c|c|c|c|c|c|c|c|c|c|c|}
\hline & \multicolumn{2}{|c|}{ Neonatal } & \multirow{2}{*}{\multicolumn{2}{|c|}{ No. }} & \multirow{2}{*}{$\begin{array}{c}\text { Birth } \\
\text { Weight } \\
\leqq 2,500 \mathrm{~g} .\end{array}$} & \multicolumn{2}{|c|}{ Asphyxia } & \multirow{2}{*}{$\begin{array}{c}\text { Complicated } \\
\text { Delivery }\end{array}$} & \multirow{2}{*}{$\begin{array}{l}\text { Immune } \\
\text { Anti-bodies } \\
\text { Found }\end{array}$} & \multirow{2}{*}{$\begin{array}{l}\text { History of } \\
\text { Icterus } \\
\text { in Sibs }\end{array}$} \\
\hline & Icterus & Asphyxia & & & & I & III & & & \\
\hline $\begin{array}{l}\mathbf{A} \\
\mathbf{B} \\
\mathbf{C}\end{array}$ & $\begin{array}{l}+ \\
+ \\
+\end{array}$ & $\begin{array}{l}- \\
+ \\
+\end{array}$ & $\begin{array}{l}98 \\
35 \\
31\end{array}$ & & $\begin{array}{l}38.8 \% \\
45.7 \% \\
12.9 \%\end{array}$ & $\begin{array}{r}68.6 \% \\
9.7 \%\end{array}$ & $\begin{array}{l}17 \cdot \overline{1} \% \\
61 \cdot 3 \%\end{array}$ & $\begin{array}{l}38 \cdot 8 \% \\
51 \cdot 4 \% \\
61 \cdot 3 \%\end{array}$ & $\begin{array}{r}52.0 \% \\
22.9 \% \\
3.2 \%\end{array}$ & $\begin{array}{l}34.7 \% \\
11.4 \% \\
9.7 \%\end{array}$ \\
\hline $\begin{array}{l}\text { Difference } \\
\text { Difference } \\
\text { Difference }\end{array}$ & $\begin{array}{l}\text { A-B } \\
0 \% \\
B-C \\
0 \% \\
\text { A-C } \\
0 \%\end{array}$ & $\begin{array}{l}\ldots \\
\cdots \\
\cdots \\
\cdots\end{array}$ & $\begin{array}{l}\cdots \\
\ddot{*} \\
\ddot{*} \\
\cdots\end{array}$ & $\begin{array}{l}\ldots \\
\ldots \\
\ldots \\
. . \\
. .\end{array}$ & $\begin{array}{r}6.9 \\
>5 \\
32.8 \\
0.2 \\
25.9 \\
<0.1\end{array}$ & $\begin{array}{r}58.9 \\
<0.1\end{array}$ & $\begin{array}{l}44 \cdot 2 \\
<0 \cdot 1\end{array}$ & $\begin{array}{c}12.6 \\
>5 \\
9.9 \\
>5 \\
22.5 \\
2.5\end{array}$ & $\begin{array}{r}29.1 \\
0.1 \\
19.7 \\
1.0 \\
48.8 \\
<0.1\end{array}$ & $\begin{array}{r}23.3 \\
0.1 \\
1.7 \\
>5 \\
25.0 \\
<0.1\end{array}$ \\
\hline
\end{tabular}

presence of immune antibodies. Table 3 shows that Group C, cases with a history of asphyxia but no icterus, differ significantly in several respects from both groups of cases with neonatal icterus.

In Table 4 the three groups $\mathrm{A}, \mathrm{B}$, and $\mathrm{C}$ are correlated with various neurological defects. Here again group $\mathrm{C}$, post-asphyxial without icterus, differs significantly from the post-icteric groups. The differences are especially significant with regard to degree of motor handicap, impaired hearing, and impairment of upward gaze, in spite of the fact that only a minority of patients were examined for the last-mentioned sign. The post-icteric cases have less motor handicap, less hyperkinesia, less speech defect, and less epilepsy; they have more often normal intelligence and more often a normal electroencephalogram. On the other hand, they have more often strabismus. Reduced hearing and impairment of upward gaze are only found among post-icteric cases.
The difference with respect to hearing loss between the post-icteric and post-asphyxic cases was described in 1957 by the present author, and in 1963 by Churchill and Colfelt, who also emphasized the difference with regard to impairment of upward gaze.

The two groups of cases in the present athetosis series, (A) cases with icterus and without asphyxia, and $(C)$ cases without icterus and with asphyxia (Table 4), were examined for other possible neurological differences. Since a clinical classification into the post-icteric or the post-asphyxial group does not seem to be possible in the individual patient on the basis of his neurological signs, an analysis has been made of all the patients of each group, with regard to five clinical signs: Babinski, ankle clonus, increased knee-jerk, rigidity, and contracture. The frequency with which any one of the signs was absent in the patients of each group, as well as how often two, three, four, or all five signs were absent, have been examined. A significant
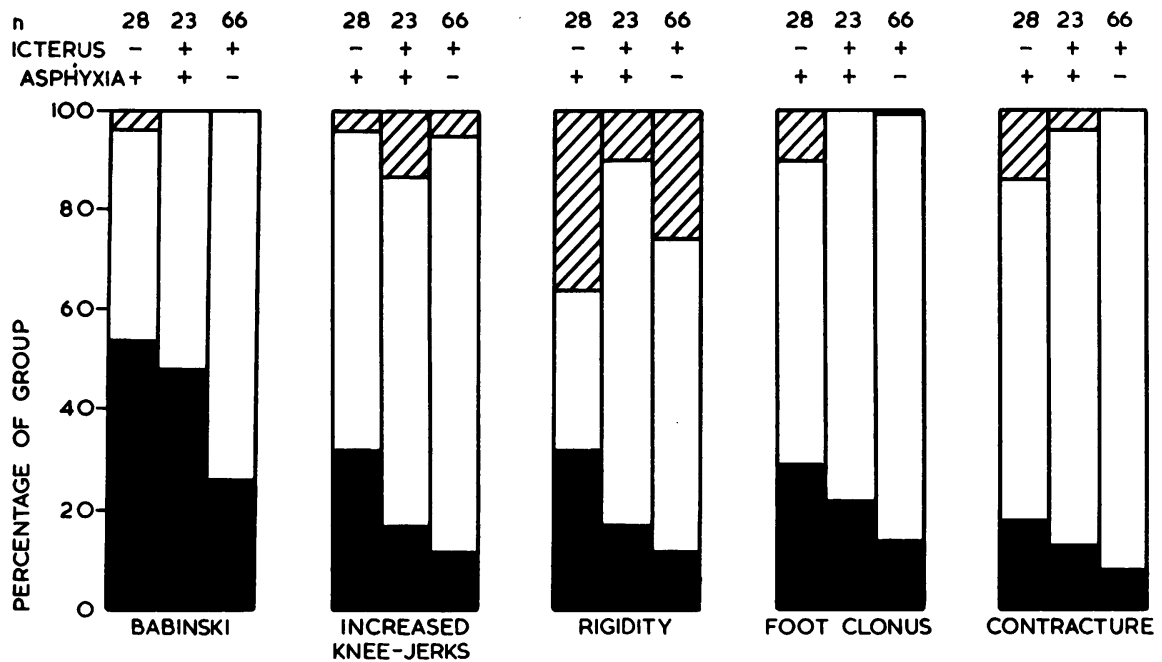

Fig. 3.-Correlation between neonatal history of icterus and asphyxia, and late neurological signs. Black area $=$ positive sign; white area $=$ negative sign; and hatched area $=$ doubtful sign or not examined. 


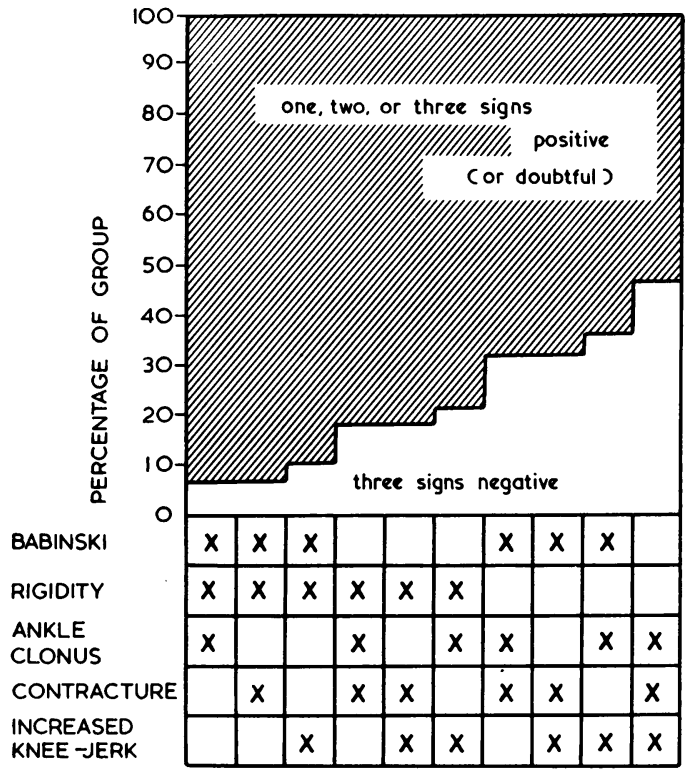

(a)

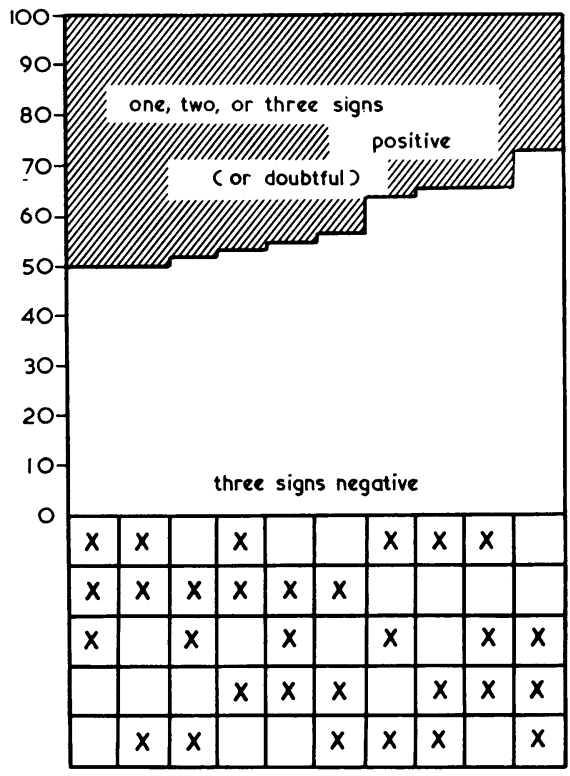

(b)

Fig. 4. - Correlation between neonatal history of icterus and asphyxia, and late neurological signs. (a) 31 cases with asphyxia and without icterus. (b) 98 cases with icterus and without asphyxia.

difference between the two groups of patients, the post-icteric and the post-asphyxial cases, was found in all but one of the 31 possible combinations of signs.

Some of the data from this analysis are presented graphically in Figs. 3 and 4.

The over-all result of the neurological analysis of the material is that the post-asphyxial cases of athetosis are more often 'spastic' than the posticteric cases. On the other hand, no one of the five signs, by its presence or absence, permits a classification of an individual patient in either group, nor does any combination of negative signs permit such a classification.
Combined Neonatal Asphyxia and ICterus. Cases with neonatal icterus not due to immunization have neonatal asphyxia in $37 \cdot 1 \%$ and cases with icterus due to immunization have neonatal asphyxia in $13.6 \%$ (Table 2 ). This difference is not likely to be due to chance $(\mathrm{p} 0 \cdot 13 \%)$. Since the incidence of neonatal asphyxia is higher in both groups than normally, it must be assumed that asphyxia in some way facilitates the damaging effect of hyperbilirubinaemia. It seems difficult, however, to understand why neonatal asphyxia should play a greater aetiological role in cases without than in cases with immunization.

Lucey, Hibbard, Behrman, Esquivel de Gallardo,

RELATION BETWEEN NEONATAL HISTORY, WITH REGAंg்

\begin{tabular}{|c|c|c|c|c|c|c|c|c|c|c|}
\hline $\mathbf{A}$ & + & - & 66 & & $50 \cdot 0 \%$ & $28 \cdot 8 \%$ & $44.0 \%$ & $13 \cdot 6 \%$ & $30 \cdot 3 \%$ & $28.8 \%$ 三. \\
\hline B & + & + & 23 & & $34 \cdot 8 \%$ & $26 \cdot 1 \%$ & $47 \cdot 8 \%$ & $26 \cdot 1 \%$ & $21 \cdot 7 \%$ & $47.8 \% \mathrm{~N}$ \\
\hline $\mathrm{C}$ & - & + & 28 & & $10 \cdot 7 \%$ & $64 \cdot 3 \%$ & $21.4 \%$ & $53 \cdot 5 \%$ & $7 \cdot 1 \%$ & $46.4 \% \mathrm{~N}$ \\
\hline $\begin{array}{l}\text { Difference } \\
\text { Difference } \\
\text { Difference }\end{array}$ & $\begin{array}{ll}\mathbf{A}-\mathbf{B} & \cdots \\
\mathbf{p} \% & \cdots \\
\mathbf{B}-\mathbf{C} & \cdots \\
\text { p \% } & \cdots \\
\mathbf{A}-\mathbf{C} & \cdots \\
\mathbf{p} \% & \cdots\end{array}$ & $\begin{array}{l}. . \\
\because \\
\because \\
\cdots \\
\cdots\end{array}$ & $\begin{array}{l}. \\
\cdots \\
\cdots \\
\cdots \\
\cdots\end{array}$ & $\begin{array}{l}. \\
\cdots \\
\cdots \\
\cdots \\
.\end{array}$ & $\begin{array}{r}15 \cdot 2 \\
>5 \\
24 \cdot 1 \\
3 \cdot .6 \\
39 \cdot 3 \\
<0.1\end{array}$ & $\begin{array}{r}2 \cdot 7 \\
>5.7 \\
38 \cdot 2 \\
0 \cdot 3 \\
35 \cdot 5 \\
0.1\end{array}$ & $\begin{array}{r}3 \cdot 8 \\
>5 \cdot 8 \\
26 \cdot 4 \\
4 \cdot 2 \\
22 \cdot 6 \\
2 \cdot 2\end{array}$ & $\begin{array}{r}12.5 \\
>5 \\
27.4 \\
3.7 \\
39.9 \\
<\quad 0.1\end{array}$ & $\begin{array}{r}8 \cdot 6 \\
>5 \\
14 \cdot 6 \\
>5 \\
23 \cdot 2 \\
0.2\end{array}$ & 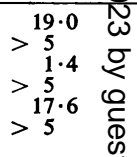 \\
\hline
\end{tabular}


and Windle (1964) injected indirect-reacting bilirubin into newborn rhesus monkeys. Only when the monkeys were asphyxiated for 10-12 minutes during caesarean section before the bilirubin injections, was it possible to produce clinical and histological signs of kernikterus.

When the cases with neonatal icterus with and without neonatal asphyxia are compared with regard to birth weight, incidence of complications at delivery (Table 3, A and B), and with regard to late clinical signs (Table 4, A and B), no differences are found. The neurological signs, however, show a systematic difference. Fig. 3 shows that each of the five neurological signs is positive more often in cases with both icterus and asphyxia than in cases solely with icterus. Even though none of the observed differences are significant, the constant finding of more positive signs in the post-asphyxial icteric cases seems to indicate that the asphyxia has modified or aggravated the brain pathology.

To conclude, it must be assumed that the presence of neonatal asphyxia in icteric infants affects both the occurrence of the brain injury and the nature of the anatomical lesion.

Degree of Neonatal Asphyxia and Late Symptoms. The question whether a correlation could be demonstrated between degree of asphyxia and late clinical signs was examined. The numbers are small (Table 2), and no conclusions can be drawn.

Neonatal Icterus of Unknown Origin as a Cause of Athetosis. The following problems arise. (1) Can physiological or idiopathic icterus, in the same way as icterus due to blood-group immunization, cause cerebral damage resulting in kernikterus and athetosis? (2) If so, what is the relative importance of physiological icterus in causing athetosis? (3) Is there any difference between the sensitized and the non-sensitized cases of athetosis? (4) Must the existence of unknown factors, which determine whether the icteric newborn is brain-damaged or not, be assumed?

(1) In this series, 71 cases of athetosis had a history of neonatal icterus without immunization, and 59 cases had a history of neonatal icterus that was probably due to blood-group immunization. The immediate answer to the first question must, therefore, be in the affirmative. The cases of this series have been grouped in Table 5 according to blood group compatibility or incompatibility of mother and child, and according to presence or absence of immune antibodies.

Reverting to the question of whether cases of athetosis with neonatal icterus not due to immunization are caused by this idiopathic icterus, or whether other aetiological factors should be considered, asphyxia is seen to be present in $26(37 \%)$ of these 71 cases. Thus asphyxia may have played a role in the aetiology of these 26 cases, but it was absent in the majority.

(2) The relative incidence of athetosis with a history of neonatal icterus of unknown origin seems to have been increasing during the past 15 years (Table 1). This is probably due to the fact that newborns with icterus due to immunization have been treated more intensively by exchange transfusion than those without immunization. It would actually seem that during the past few years, more cases of athetosis have been caused by idiopathic icterus than by icterus due to immunization.

(3) Statistical analysis of the data* has shown that in certain respects cases with a history of idiopathic icterus differ from those with icterus due to immuni-

* The author is willing to supply these statistical data on request.

TO ICTERUS AND ASPHYXIA, AND SOME LATE SIGNS

\begin{tabular}{|c|c|c|c|c|c|c|c|}
\hline \multirow{2}{*}{$\begin{array}{l}\text { Subnormal } \\
\text { Intelligence }\end{array}$} & \multirow{2}{*}{$\underset{\text { Hearing }}{\text { Impaired }}$} & \multicolumn{3}{|c|}{ Impairment of Upward Gaze } & \multirow{2}{*}{ Squint } & \multirow{2}{*}{ Epilepsy } & \multirow{2}{*}{ Abnormal EEG } \\
\hline & & - & + & $?$ & & & \\
\hline $15 \cdot 2 \%$ & $51 \cdot 5 \%$ & $13 \cdot 6 \%$ & $22 \cdot 7 \%$ & $63 \cdot 7 \%$ & $34.8 \%$ & $4 \cdot 5 \%$ & $19 \cdot 7 \%$ \\
\hline $34 \cdot 8 \%$ & $47 \cdot 8 \%$ & $26 \cdot 1 \%$ & $13 \cdot 0 \%$ & $60 \cdot 9 \%$ & $26 \cdot 1 \%$ & $4 \cdot 4 \%$ & $21 \cdot 7 \%$ \\
\hline $32 \cdot 1 \%$ & 0 & $28 \cdot 6 \%$ & 0 & $71 \cdot 4 \%$ & $14 \cdot 3 \%$ & $21 \cdot 4 \%$ & $46 \cdot 4 \%$ \\
\hline $\begin{array}{rl} & 19 \cdot 6 \\
> & 5 \\
2 \cdot 7 & 5 \\
> & 5 \cdot 9 \\
16 \cdot 9 \\
4 \cdot 2\end{array}$ & $\begin{array}{r}3.7 \\
>5 \\
47.8 \\
<\quad 0.1 \\
51.5 \\
<0.1\end{array}$ & & $\begin{array}{r}9.7 \\
>5 \\
13.0 \\
>5 \\
22.7 \\
<0.1\end{array}$ & & $\begin{array}{r}8.7 \\
>5 \\
11 \cdot 8 \\
>5 \\
20.5 \\
2.0\end{array}$ & $\begin{array}{l}0 \cdot 1 \\
>5 \\
17 \cdot 0 \\
>5 \\
16 \cdot 9 \\
3 \cdot 8\end{array}$ & $\begin{array}{c}2 \cdot 0 \\
>5 \\
24 \cdot 7 \\
5 \\
26 \cdot 7 \\
1 \cdot 2\end{array}$ \\
\hline
\end{tabular}


CORRELATION BETWEEN BLOOD GROUPS, IMMUNE ANTIBODIES, AND SOM

\begin{tabular}{|c|c|c|c|c|c|c|c|c|c|c|}
\hline \multirow{3}{*}{ No. } & \multicolumn{4}{|c|}{ Blood Groups of Mother and Child with Regard to } & \multicolumn{3}{|c|}{ Immune Anti-A or B in Mother's Blood } & \multicolumn{3}{|c|}{ Immune Anti-Rh in Mother's Bloo, } \\
\hline & \multicolumn{2}{|c|}{$A$ and $B$} & \multicolumn{2}{|c|}{$\mathbf{R h}$} & \multicolumn{2}{|c|}{ Examined } & \multirow{2}{*}{$\underset{\text { Examined }}{\text { Not }}$} & \multicolumn{2}{|c|}{ Examined } & \multirow{2}{*}{ 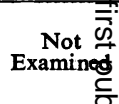 } \\
\hline & Compatible & $\begin{array}{c}\text { Not } \\
\text { Compatible }\end{array}$ & Compatible & $\underset{\text { Not }}{\text { Not }}$ & $\begin{array}{c}\text { Not } \\
\text { Found }\end{array}$ & Found & & $\begin{array}{c}\text { Not } \\
\text { Found }\end{array}$ & Found & \\
\hline $\begin{array}{r}66 \\
5 \\
9 \\
5 \\
14 \\
2\end{array}$ & $\begin{array}{l}+ \\
+ \\
+ \\
+\end{array}$ & $\stackrel{+}{+}$ & $\begin{array}{l}+ \\
+ \\
+ \\
+\end{array}$ & $\begin{array}{l}+ \\
+\end{array}$ & $\begin{array}{l}+ \\
+ \\
+\end{array}$ & & $\stackrel{+}{+}$ & $\begin{array}{l}+ \\
+ \\
+ \\
+ \\
+\end{array}$ & & 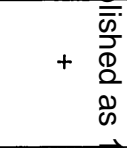 \\
\hline 101 & & & & & & & & & & $\overrightarrow{0}$ \\
\hline $\begin{array}{r}29 \\
27 \\
1 \\
4\end{array}$ & + & $\begin{array}{l}+ \\
+ \\
+\end{array}$ & + & $\begin{array}{l}+ \\
+ \\
+\end{array}$ & & $\begin{array}{l}+ \\
+\end{array}$ & + & + & $\begin{array}{l}+ \\
+ \\
+\end{array}$ & $\begin{array}{l}\vec{\omega} \\
\stackrel{\rho}{ٍ} \\
\varrho\end{array}$ \\
\hline 61 & & & & & & & & & & Th \\
\hline $\begin{array}{l}1 \\
2 \\
8\end{array}$ & & + & & + & & & $\begin{array}{l}+ \\
+ \\
+\end{array}$ & $\stackrel{+}{+}$ & & $\begin{array}{r}N \\
+\quad \frac{N}{N} \\
\end{array}$ \\
\hline 11 & & & & & & & & & & Wु \\
\hline Total 173 & & & & & & & & & & 운 \\
\hline
\end{tabular}

zation. Cases with idiopathic icterus are more often premature and they are more often asphyxiated neonatally than those with icterus due to immunization. On the other hand, there are fewer neonatal signs of kernikterus, impaired hearing, and sibs with neonatal icterus. There are no significant differences in this series with regard to the degree of icterus, the degree of motor handicap, the incidence of subnormal intelligence, the incidence of epilepsy, and the incidence of neurological signs indicating spasticity.

Fifteen of the non-sensitized children with athetosis died during early childhood. Necropsy was performed in 5 and histological signs characteristic of kernikterus were found in 4 (to be reported by Inge Tygstrup). The death rate was $29.5 \%$ in the sensitized and $17.8 \%$ in the non-sensitized group; this difference is not significant.

It is general clinical experience that the bilirubin values during the first days of life show an earlier and more rapid rise in sensitized than in non-sensitized icteric newborn. It has not been possible to obtain information on this problem from this series of cases of athetosis, since bilirubin determinations have been made in only 9 sensitized and 9 non-sensitized cases.

(4) Though it seems likely that prematurity and neonatal asphyxia add to the risk of idiopathic neonatal icterus, it is not possible at the moment to explain why an infant is affected or escapes. A search for some other factor of contributory or decisive importance seems indicated. Waters and Porter (1964) have reported that the determination of the reserve albumin-binding capacity of serum adds valuable information. If there is no albumin left for binding the unconjugated bilirubin the risk of kernikterus is great, in spite of a low serum bilirubin.

ABO Sensitization. Although there is still some uncertainty associated with demonstrating $\mathrm{ABO}$ sensitization in the individual case, it is generally accepted that ABO sensitization is of aetiological importance for neonatal icterus and subsequent brain disease.

To elucidate the question as to whether a relationship could be demonstrated between ABO incompatibility and athetosis the following analyses were made. (a) A comparison between the blood groups of mother and child in the present material and the general population. (b) A comparison of the incidence of various neonatal and late signs within the three groups of cases, ABO-incompatibility, $\mathrm{Rh}$-incompatibility, and post-icteric cases without incompatibility.

(a) Dr. J. Schultz-Larsen, Institute of Human Genetics, University of Copenhagen, has kindly carried out the calculations. The main results were as follows. The total material shows that the number of observed cases of ABO-incompatibility and $\mathbf{R h}$-incompatibility are significantly greater than in the general population $\left(\chi^{2}=6 \cdot 4, f=1,2 \%>p\right.$ 
ANAMNESTIC DATA IN THE ATHETOSIS SERIES (ABSOLUTE NUMBERS; ALL CASES INCLUDED)

\begin{tabular}{|c|c|c|c|c|c|c|c|c|c|c|c|}
\hline \multirow{2}{*}{$\begin{array}{c}\begin{array}{c}\text { Birth } \\
\text { Weight }\end{array} \\
2,900 \mathrm{~g} .\end{array}$} & \multicolumn{4}{|c|}{ Neonatal Icterus } & \multicolumn{3}{|c|}{ Neonatal Asphyxia } & \multirow{2}{*}{$\begin{array}{l}\text { Icterus } \\
\text { in Sibs }\end{array}$} & \multirow{2}{*}{$\begin{array}{c}\text { Signs of } \\
\text { Kernikterus }\end{array}$} & \multirow{2}{*}{$\begin{array}{l}\text { Reduced } \\
\text { Hearing }\end{array}$} & \multirow{2}{*}{$\begin{array}{c}- \\
\text { Icterus } \\
+ \\
\text { Asphyxia }\end{array}$} \\
\hline & + & - & Unknown & Icterus III & + & - & Unknown & & & & \\
\hline $\begin{array}{r}31 \\
3 \\
4 \\
1 \\
4 \\
1 \\
\end{array}$ & $\begin{array}{r}46 \\
5 \\
4 \\
4 \\
10 \\
2\end{array}$ & $\begin{array}{r}20 \\
0 \\
4 \\
1 \\
4 \\
0 \\
\end{array}$ & $\begin{array}{l}0 \\
0 \\
1 \\
0 \\
0 \\
0\end{array}$ & $\begin{array}{r}23 \\
2 \\
2 \\
1 \\
7 \\
1\end{array}$ & $\begin{array}{r}34 \\
1 \\
8 \\
4 \\
5 \\
0\end{array}$ & $\begin{array}{r}32 \\
4 \\
1 \\
1 \\
8 \\
2 \\
\end{array}$ & $\begin{array}{l}0 \\
0 \\
0 \\
0 \\
1 \\
0\end{array}$ & $\begin{array}{r}10 \\
0 \\
0 \\
1 \\
1 \\
0\end{array}$ & $\begin{array}{r}19 \\
2 \\
4 \\
2 \\
3 \\
1\end{array}$ & $\begin{array}{r}16 \\
2 \\
1 \\
1 \\
2 \\
1 \\
\end{array}$ & $\begin{array}{r}16 \\
0 \\
4 \\
1 \\
3 \\
0\end{array}$ \\
\hline 44 & 71 & 29 & 1 & 36 & 52 & 48 & 1 & 12 & 31 & 23 & 24 \\
\hline $\begin{array}{r}3 \\
10 \\
1 \\
0\end{array}$ & $\begin{array}{r}29 \\
25 \\
1 \\
4\end{array}$ & $\begin{array}{l}\mathbf{0} \\
2 \\
\mathbf{0} \\
\mathbf{0}\end{array}$ & $\begin{array}{l}0 \\
0 \\
0 \\
0 \\
\end{array}$ & $\begin{array}{r}21 \\
15 \\
1 \\
2\end{array}$ & $\begin{array}{l}3 \\
5 \\
0 \\
1\end{array}$ & $\begin{array}{r}26 \\
22 \\
1 \\
3\end{array}$ & $\begin{array}{l}0 \\
0 \\
0 \\
0\end{array}$ & $\begin{array}{r}14 \\
13 \\
1 \\
2\end{array}$ & $\begin{array}{r}22 \\
17 \\
0 \\
2\end{array}$ & $\begin{array}{r}15 \\
12 \\
1 \\
2\end{array}$ & $\begin{array}{l}0 \\
1 \\
0 \\
0\end{array}$ \\
\hline 14 & 59 & 2 & 0 & 39 & 9 & 52 & 0 & 30 & 41 & 30 & 1 \\
\hline $\begin{array}{l}\mathbf{0} \\
\mathbf{0} \\
\mathbf{2} \\
\end{array}$ & $\begin{array}{l}1 \\
1 \\
2\end{array}$ & $\begin{array}{l}0 \\
1 \\
5\end{array}$ & $\begin{array}{l}0 \\
0 \\
1\end{array}$ & $\begin{array}{l}1 \\
1 \\
0\end{array}$ & $\begin{array}{l}0 \\
1 \\
6\end{array}$ & $\begin{array}{l}1 \\
1 \\
2\end{array}$ & $\begin{array}{l}0 \\
0 \\
0 \\
\end{array}$ & $\begin{array}{l}\mathbf{0} \\
\mathbf{0} \\
\mathbf{0}\end{array}$ & $\begin{array}{l}1 \\
1 \\
1\end{array}$ & $\begin{array}{l}0 \\
1 \\
2\end{array}$ & $\begin{array}{l}0 \\
1 \\
5\end{array}$ \\
\hline 2 & 4 & 6 & 1 & 2 & 7 & 4 & 0 & 0 & 3 & 3 & 6 \\
\hline 60 & 134 & 37 & 2 & 77 & 68 & 104 & 1 & 42 & 75 & 56 & 31 \\
\hline
\end{tabular}

irregular immune antibodies.

$>1 \%$, and $\chi^{2}=49 \cdot 6, \mathrm{f}=1, \mathrm{p}<0 \cdot 1 \%$, respectively).

The Rh-compatible part of the material shows that the observed number of cases of ABO-incompatibility is significantly greater than expected $\left(\chi^{2}=10 \cdot 1\right.$, $\mathrm{f}=1, \mathrm{p}<0.1 \%$ ).

The ABO-compatible part of the material shows that the observed number of cases of $\mathrm{Rh}$-incompatibility is significantly greater than expected $\left(\chi^{2}=56 \cdot 7\right.$, $\mathrm{f}=1, \mathrm{p}<0 \cdot 1 \%$ ). The $\mathrm{Rh}$-incompatible part of the material shows that the observed number of cases of ABO-incompatibility is not greater than expected. The ABO-incompatible part of the material shows that the observed number of cases of Rh-incompatibility is not greater than expected. The expected frequencies of compatibility and incompatibility between mother and child with respect to $\mathrm{ABO}$ were calculated on the basis of the gene frequencies given by Goldschmidt (1961), and with respect to $R h$ on the basis of the gene frequencies given by Gürtler and Henningsen (1954).

(b) The ABO-incompatible cases lie between the ABO- and Rh-compatible and the Rh-incompatible cases with regard to the incidence of the various signs examined, suggesting that $\mathrm{ABO}$-incompatibility is of importance, but less so than $\mathrm{Rh}$ incompatibility. Cases with immune anti-A or immune anti-B lie between those without immune antibodies and those with Rh-antibodies. The greatest difference between ABO-sensitized and $\mathrm{Rh}$-sensitized children is the greater incidence of prematurity in the former, which likewise includes a greater number of patients with neonatal asphyxia.

If those cases without neonatal icterus are ignored, no differences with regard to late signs were found between sensitized and non-sensitized cases.

Prematurity. Prematurity was found in $35 \%$ of the total series of athetosis cases, in $40 \%$ in the group of athetosis with neonatal icterus, and in $56 \%$ in the group of athetosis with idipoathic icterus. With respect to idiopathic icterus, it must be supposed, therefore, that premature infants are either 20 times (i.e. $\frac{94}{6} \times \frac{56}{44}$ ) as often jaundiced as full-term infants, or that they are 20 times as sensitive to the same level of hyperbilirubinaemia as full-term infants. Since it was found that a certain high bilirubin level was reached only about four times as often by prematures as by full-term infants, it must be concluded either that premature infants are five times as sensitive as full-term infants at a certain degree of hyperbilirubinaemia, or that the critical level of bilirubin is lower for prematures. Trolle (1965) in an examination for the incidence of icterus of unknown origin, found that only duration of pregnancy was of importance. Of children with a birth weight from 2,000 to 2,500 g., those born at term had lower serum bilirubin than those born before term. Trolle suggested that this was probably due to an enzyme deficiency in the liver cells of the premature infants. 
On the basis of the present series of athetosis cases, the figures have been examined for any correlation between birth weight and late signs. Only one difference was found, matures were more often of subnormal intelligence than prematures. The difference, however, was of slight significance $(p=3 \cdot 8 \%)$.

\section{Summary and Conclusions}

Based on a series of 173 cases of congenital athetosis, the relative importance of the following aetiological factors was examined: neonatal asphyxia, idiopathic or physiological icterus, ABO- and Rhsensitization, and prematurity.

Of 173 patients, 31 had a history of neonatal asphyxia without neonatal icterus. This group of post-asphyxial cases differed significantly in several respects from the group of post-icteric cases. The most pronounced differences were found with respect to impaired hearing and impairment of upward gaze, these signs being present only in the post-icteric group. An analysis of the neurological signs showed significant differences between the two groups, the post-asphyxial group showing more cases with signs of spasticity than the post-icteric group.

A history of both neonatal asphyxia and neonatal icterus was less often found in the blood-group sensitized children than in the non-sensitized. The group with both asphyxia and icterus showed a greater incidence of neurological signs indicating spasticity than the post-icteric group, but a smaller incidence of such signs than the post-asphyxial group.

Neonatal asphyxia must be supposed to facilitate the pathological process leading to kernikterus.

More cases developed athetosis from idiopathic icterus than from icterus due to immunization. The group with idiopathic icterus differed significantly from that with icterus due to sensitization in the following respects: birth weight, incidence of neonatal asphyxia, incidence of kernikteric signs, incidence of impaired hearing, and incidence of cases with icterus among sibs. There were no significant differences between the two groups with regard to degree of icterus, degree of motor handicap, incidence of subnormal intelligence, incidence of epilepsy, and incidence of neurological signs indicating spasticity.

Of the 71 non-sensitized infants with athetosis, 15 died during early childhood. Necropsy showed histological signs characteristic of kernikterus in 4 out of 5 (Dr. Inge Tygstrup).

The question of ABO-sensitization is still associated with difficulties of definition. The incidence of ABO- and Rh-incompatibility between mother and child has, therefore, been examined in the athetosis series and compared with the corresponding incidence in the general population. The results indicate that ABO-immunization is of aetiological importance in neonatal icterus.

With regard to the incidence of certain neonatal factors, the group of cases with ABO immune antibodies was found to lie between the group without immune antibodies and the group with $\mathrm{Rh}$-antibodies.

The incidence of prematurity was greater in posticteric than in post-asphyxia cases, and greater in non-sensitized than in sensitized cases. The susceptibility of premature infants to kernikterus is about 5 times greater than that of full-term infants.

REFERENCES

Churchill, J. A., and Colfelt, R. H. (1963). Etiologic factors in athetotic cerebral palsy. Arch. Neurol. (Chic.), 9, 400.

Goldschmidt, E. (1961). Variations in the ABO blood group distribution in Denmark. Acta genet. (Basel), 11, 85.

Gürtler, H., and Henningsen, K. (1954). Rh-chromosome frequencies in the Danish population. Acta. path. microbiol. scand., 34, 493.

Lucey, J. F., Hibbard, E., Behrman, R. E., Esquivel de Gallardo, F. O., and Windle, W. F. (1964). Kernicterus in asphyxiated newborn rhesus monkeys. Exp. Neurol., 9, 43.

Munk-Andersen, G. (1956). A dextran serum medium for the demonstration of incomplete anti-A and anti-B. Acta path. microbiol. scand., 38, 259.

Plum, P. (1957). Etiology of congenital athetosis. Ann. Paediat. Fenn., 3, 589.

Trolle, D. (1965). Danish med. Bull. In the press.

Waters, W. J., and Porter, E. (1964). Indications for exchange transfusion based upon the role of albumin in the treatment of hemolytic disease of the newborn. Pediatrics, 33, 749. 